\title{
A representação na obra ficcional de Frei Betto
}

\author{
André Jorge Catalan Casagrande*
}

Resumo: O presente artigo analisa a representação na obra ficcional de Frei Betto. Além de constatar os tipos de personagens e grupos presentes nos romances bettianos, investigará como o externo, isto é, o aspecto social, cultural, histórico, psicológico etc., é utilizado como matériaprima pelo autor para construção tanto de suas personagens quanto dos grupos sociais representados em seus romances. O intuito é perceber como Betto transpõe a realidade para a ficção ou o modo pelo qual ele constrói os sujeitos por ele representados. Tal análise será feita a partir das mais recentes teorias da representação literária.

Palavras-chave: Representação. Tortura. Literatura contemporânea brasileira.

\begin{abstract}
This article analyzes the representation in the fictional work of Frei Betto. In addition verifying the types of characters and groups present in Bettian novels, will investigate as external, that is, the social, cultural, historical, psychological etc., is used as a raw material by the author to build his characters and of the social groups represented in his novels. The aim is understand how Betto transposes reality to fiction or the way that he builds the subject by him represented. The analysis will be based on the most recent theories of literary representation.
\end{abstract}

Key-words: Representation. Torture. Contemporany brazilian literature.

Resumen: Este artículo analiza la representación en el trabajo ficticio de Frei Betto. Además de verificar los tipos de personajes y grupos presentes en las novelas bettianas, investigará cómo el autor utiliza el aspecto externo, es decir, el aspecto social, cultural, histórico, psicológico, etc., es utilizado como materia prima por el autor para construir sus personajes e los grupos sociales representados en sus novelas. El objetivo es comprender cómo Betto transpone la realidad a la ficción o la forma en que construye los temas que representa. Dicho análisis se realizará a partir de las teorías más recientes de la representación literaria.

Palabras-clave: Representación. Tortura. Literatura brasileña contemporánea.

\section{Introdução}

* Doutor em Letras pela Universidade Presbiteriana Mackenzie. http://orcid.org/0000-0002-5705-0792 
Frei Betto é um autor popular, contando atualmente com mais de 60 títulos publicados individualmente - somados a outros 46 escritos em coautoria - entre romances, contos, crônicas e ensaios sobre os mais variados assuntos. O êxito de sua carreira como escritor pode ser constatado pelas largas tiragens, reedições e traduções de seus livros ao longo de uma carreira literária com aproximadamente 50 anos. Embora a obra de um autor vivo não tenha passado pelo crivo do tempo a fim de ser testada, o estudo de Frei Betto se justifica pela circulação significativa de suas obras há algumas décadas. Se compreendermos a literatura como uma maneira de intervenção no mundo, faz sentido o estudo desse autor para que se conheça sua obra, pergunte-se pelas suas principais características e se procure compreender que tipo de representação da realidade ela sugere. Este artigo, portanto, tem intenção de investigar a representação presente na obra deste escritor mineiro partindo de três de seus romances: O dia de Ângelo (1987), Hotel Brasil (2010) ${ }^{1}$ e Aldeia do silêncio (2013).

\section{Teorias modernas da representação}

Segundo as teorias modernas, a representação sempre se dará a partir de um quadro ideológico. Sendo assim, é inevitável que a representação ofereça uma cosmovisão da realidade. A conceituação moderna nos leva a apreender que o processo de "representação" estará sempre alicerçado em uma disputa dialética por poder. As reflexões de Christopher Prendergast estão focadas não no objeto representado, como ocorria nas antigas teorias da representação, mas, sim, no sujeito da representação propriamente dito. Nas palavras do próprio Prendergast:

Para Barthes, a imagem do triângulo da representação é expressamente designada para realçar a economia de autoridade e hierarquia, uma relação de poder na qual o sujeito da representação comanda o sistema de conhecimento e a crença dentro da qual o mundo é interpretado e as interpretações validadas socialmente (PRENDERGAST, 200o, p. 11, tradução nossa).

\footnotetext{
${ }^{1}$ O romance Hotel Brasil foi publicado pela primeira vez em 1999. Neste artigo, no entanto, para fins de citação utilizaremos a edição de 2010, publicada pela editora Rocco, conforme referência bibliográfica.
} 
O que significa dizer que é o sujeito da representação - no caso da literatura, o autor $^{2}$ - quem, a partir de seu ponto de vista, de sua classe social, de suas crenças, de seu posicionamento político-ideológico etc., sugerirá o retrato daquilo que há de ser representado. Não há, portanto, neutralidade no processo representativo. Não podemos imaginá-lo como mera "imitação" da realidade. A representação se torna, desse modo, revestida de uma conotação política, em que o autor será dono de uma perspectiva social própria que norteará seu processo criativo. Segundo Prendergast, é justamente a mudança de foco do objeto para o sujeito da representação que, de alguma forma, alterará as concepções modernas acerca das teorias representativas. Há outro excerto de Prendergast que pavimenta ainda mais o caminho que estamos trilhando:

Na descrição tradicional da representação, o foco está naquilo que é representado; na teoria contemporânea, o foco está no processo da representação, na questão de quem faz a representação, quem delimita e controla o campo da representação; em resumo, há um deslocamento do objeto da representação para o sujeito da representação (PRENDERGAST, 2000, p. 9, tradução nossa).

Por essa conceituação da representação como um triângulo, "no ápice do triângulo há o sujeito da visão, um sujeito centrado e unificado que corta, delimita e controla o campo" (PRENDERGAST, 2000, p. 10, tradução nossa). Será, portanto, a perspectiva do autor que encontrará representatividade em sua obra, ou pode ser ainda que o autor represente a perspectiva ideológica de um grupo, por exemplo. A questão aqui não é simplesmente questionar o engajamento da arte - até porque, toda arte é necessariamente engajada, sem, contudo, necessariamente ser panfletária -, mas compreender que as escolhas de um autor têm consequências sociais, históricas, culturais e ideológicas.

\footnotetext{
${ }^{2}$ É preciso dizer que nem sempre o sujeito será necessariamente um indivíduo (no caso da arte, um autor), podendo ser até um grupo. Para Prendergast (2011), esse sujeito pode estar ligado "à moda, a uma ideologia, a uma tradição ou convenções, frequentemente conectadas a um conjunto dominante de interesses (um grupo social, uma classe dominante, que privilegiou o acesso aos recursos culturais de uma sociedade). O que não significa que a representação possa estar separada de intenções individuais [...]” (p. 11, tradução nossa).
} 
Quanto ao sujeito da representação, é necessário afirmar que ele sempre é produzido social e culturalmente; daí o entendimento de que as representações serão mais plurais e menos estereotipadas quando houver uma maior democratização do fazer literário. Contudo, segundo Prendergast (2000), há sempre uma tendência de se mascarar a relatividade desse sujeito - em um gesto de poder -, pela qual cultura e história acabam sendo transformadas em imagens naturais. Isso significa que a cultura e a história acabam por ser vistas como verdades absolutas e universais, como se não houvesse outras possibilidades de se pensar a realidade. As representações, por sua vez, nessa ótica interpretativa, tornam-se mera imitação de um universo monocromático. É contra a imposição de uma representatividade autoritária e opressiva - seja ela literária, artística ou cultural - que Prendergast emerge. Em seus apontamentos, ele questiona: "se representação é o processo pelo qual “a” significa "b" (onde "a" e "b” podem ser termos de um sistema linguístico, literário ou político), por meio de que autoridade isso se dá?” (PRENDERGAST, 200o, p. 8, tradução nossa). A autoridade de legitimação de um discurso se dá por meio do poder. Prendergast afirmará que poder, representação e literatura caminham de mãos dadas:

No caso da literatura, as representações são mais bem vistas como forças de trabalho no campo de força da cultura; nesse sentido, estão irredutivelmente ligadas com o poder. Ficções literárias não simplesmente descrevem ou refletem o mundo. Elas desencadeiam, precisamente pelo caminho do modo ficcional de representação, atitudes para com o mundo que autorizam/habilitam - ou desautorizam/desabilitam - formas de compreensão. Esta é uma das coisas mais importantes que a literatura faz (PRENDERGAST, 2000, p. 15, tradução nossa).

Diante do exposto, resta-nos a pergunta: o que nos cabe fazer como estudiosos da literatura? Como podemos considerar a questão da representação? O conselho de Prendergast é o seguinte: “O que nós podemos tentar fazer - esta é uma das lições da teoria moderna - é atenuar a relação entre representação e poder questionando todas as representações dominantes" (PRENDERGAST, 2000, p 13, tradução nossa, grifo do autor).

No que diz respeito, especificamente, à literatura brasileira contemporânea, na qual Frei Betto se insere, os estudos de Regina Dalcastagnè auxiliarão na compreensão 
da representação dos grupos sociais. Para ela, as escolhas miméticas dos autores, compostas, sobretudo, pelos grupos sociais, bem como pela forma como esses grupos são representados em suas obras literárias, partem de uma estratégia ideológica consciente ou não - que pode, muito bem, vir a possuir reverberações excludentes, quando não abarca o bojo da sociedade representada, ou includentes, quando abrange grupos minoritários e sem representatividade social.

É justamente por meio da mimesis que se dá o processo de representação de grupos sociais na literatura. De modo que os gays, os negros, os favelados, os menores abandonados ou quaisquer outros grupos são transpostos para o universo literário por meio de um processo mimético. Assim, será o sujeito da representação quem, a partir de sua percepção da realidade, escolherá os grupos sociais que adentrarão à sua narrativa, além da maneira como esse grupo será representado artisticamente em sua obra literária.

Ao analisar a representação proposta por Frei Betto em sua obra romanesca, nossa intenção é a de compreender o significado dessas representações, bem como compreender a maneira como os indivíduos e os grupos sociais são construídos por esse autor, a fim de transmitir uma determinada mensagem. Tenciona-se, desse modo, entender quais grupos são alçados à posição de mais valor e quais são desvalorizados em seus romances, além de se pensar a estratégia textual utilizada pelo autor para tanto.

\section{A representação em $O$ dia de Ângelo}

Existem inúmeros relatos historiográficos a respeito do período da ditadura militar que assolou o Brasil, entre os anos de 1964 e 1985. Alguns desses textos, ainda que memorialísticos, foram escritos pelo próprio Frei Betto. Batismo de Sangue, publicado pela primeira vez em 1983, prêmio Jabuti na categoria de melhor livro de memórias, além de ter se tornado roteiro de filme em 2007, possivelmente seja o mais conhecido deles. Além desse clássico, Frei Betto ainda escreveu outros livros a respeito do mesmo 
período: Cartas da prisão - 1969-1973 (1974), Das catacumbas (1976), Diário de Fernando - Nos cárceres da ditadura militar brasileira (2009).

Se Frei Betto já havia escrito outros textos sobre a ditadura, respaldado em suas memórias a respeito daquele período, por que escrever um romance sobre o mesmo assunto? Qual seria o ganho (se é que ele existe)? O que O dia de Ângelo (1987) oferece de diferente dos demais relatos memorialísticos e historiográficos do autor?

A fim de responder aos questionamentos anteriormente levantados, recorreremos a um exercício de imaginação proposto por Richard Rorty (1999). Imaginese que a sociedade ocidental fosse totalmente extinta e dela nada restasse, a não ser alguns poucos livros, revistas, filmes e obras de arte, arquivadas clandestinamente em porões de universidades do leste asiático e da África subsaariana por pessoas interessadas em preservar o pouco que restou da cultura ocidental. Imagine-se, ainda, que quinhentos anos após o ocorrido, os bunkers onde foram postos os resquícios da cultura ocidental fossem descobertos e a história do Ocidente recontada a partir dos títulos encontrados. Quais textos dariam uma melhor dimensão da cultura, do pensamento e da historiografia ocidental? Um texto filosófico? Um texto historiográfico? Um texto memorialístico? Ou um romance? Segundo Rorty (1999), Heidegger acreditava "que a essência de uma época histórica poderia ser descoberta lendo as obras do filósofo característico dessa época [...]” (p. 97). Não obstante, na perspectiva de Rorty, o gênero que melhor captaria a essência da civilização ocidental seriam os romances, e não os tratados filosóficos ou historiográficos. Ao contrapor os escritos filosóficos de Martin Heidegger aos escritos romanescos de Charles Dickens, Rorty (1999, p. 97) faz a seguinte afirmação:

Se meus asiáticos e africanos imaginários fossem, por alguma razão, incapazes de preservar as obras desses dois homens, eu preferiria em muito que eles preservassem a de Dickens. Pois Dickens poderia ajudá-los a apreender um complexo de atitudes que foram importantes para o Ocidente.

Esse "complexo de atitudes" seria aquele presente nas personagens do autor inglês, capazes de gerar identificação com o leitor, criando um forte sentimento de empatia desses para com aqueles. O mesmo parece ocorrer em $O$ dia de Ângelo (1987), 
uma vez que Betto cria uma personagem pacata e angelical que sofre de maneira horrenda e desumana nas mãos dos militares. A narrativa cria, portanto, um sentimento de empatia do leitor para com a personagem-título, bem como um sentimento de aversão do leitor para com os militares.

Além disso, pela ótica rortyana, percebe-se que uma obra romanesca representará a sociedade e a cultura de um povo de maneira mais completa e mais contundente do que um tratado filosófico ou historiográfico. Isso ocorre porque, na narrativa, diferentemente de um texto meramente teórico, há maior riqueza de detalhes, há maior diversidade, há diferentes pontos de vista, que acabam por tornar esse gênero literário mais democrático e libertário. No romance não há uma verdade única, podendo-se apresentar o mundo de forma relativa e ambígua. Além do que, o romance apresentaria uma percepção mais aguçada do mundo, dos sentimentos humanos, das ideias presentes em determinada época, bem como uma cosmovisão mais ampla da vida.

Um dos ganhos do romance em detrimento de outros gêneros, citando o caso específico do romance $O$ dia de Ângelo, é o fato de ele potencializar os sentimentos e as emoções daquele que se encontra sob a condição de tortura. $\mathrm{O}$ romance aponta suas reações psicológicas, demonstrando seu amedrontamento diante de determinadas situações. Ao ouvir o carcereiro se aproximar de sua cela, durante a madrugada, o narrador nos apresenta o sofrimento psicológico protagonizado por Ângelo:

\footnotetext{
Por que viria agora? A noite traz prenúncios horripilantes, principalmente quando a imaginação não decifra ruídos, sofre-os. Nos primeiros anos, o que não estava devidamente codificado pela rotina carcerária conduzia a imaginação a voos que beiravam o pânico. Escutar, em plena madrugada quando o silêncio e a escuridão abraçam-se, conspirativos -, o arranhar de grades que se abrem, o urro crispado de um prisioneiro, o motor acelerado de viaturas que chegam, era suficiente para cortar o sono, agitar o sangue, dilatar os olhos, enrijecer os músculos, multiplicar as batidas do coração e o ritmo ofegante da respiração. Alucinado, o cérebro rodopiava como piorra sem rumo (BETTO, 1987, p. 22).
}

Tal cena fornece a representação das emoções entranhadas em um prisioneiro político encarcerado durante o regime militar brasileiro. Além do que, em outro momento, o narrador nos diz que Ângelo se encontrava "interiormente desordenado, não sabia se refletia, dormia, rezava ou deixava a mente vagar, como se resistisse à ideia 
de se encontrar encerrado na solitária e não quisesse enfrentar tão crua realidade" (BETTO, 1987, p. 33). Na sequência, sentimos a aflição da personagem-título ao não conseguir se entregar ao sono:

O sono não vinha. Virava a cabeça de um lado, virava de outro, naquele excitante estado de entorpecimento forçado que precede e se prolonga por todas as insônias [...] Seu corpo não cabia naquela cama. Dobrava-se à direita, recolhia as pernas junto ao ventre, afundava a cabeça no travesseiro, puxava o lençol sobre os olhos para tentar reduzir a claridade disseminada pela lâmpada permanentemente acesa. Era como se uma comichão subcutânea o percorresse, eletrizando nervos, músculos, veias, avivando o cérebro que escorregava vertiginosamente por uma montanha-russa circular [...] Tornava a esticar as pernas, ficar de bruços, em busca de uma posição que o relaxasse e trouxesse sono. Mas o sono parecia longínquo à agitação interior que o remexia na angustiante vigília [...] Irritado com a impossibilidade de desacelerar o cérebro, como o vizinho da igreja não pode desligar o tic-tac do relógio da torre, Ângelo P. retirou a venda dos olhos (BETTO, 1987, p. 34-35).

A narrativa fomenta ainda a ideia de que a própria mente é a maior inimiga de um homem solitário, encarcerado e ocioso. Anteriormente à solitária, Ângelo passava os dias lendo e escrevendo na cela da prisão, sendo esse, inclusive, o motivo de sua alta periculosidade. Contudo, os livros, os papéis e as canetas foram retirados dele. Sua mente, agora, se mantinha ociosa, tornando-se, por sua vez, mais suscetível a surtos psicóticos. O narrador, então, nos diz que:

[...] em condições adversas como o cárcere, a imaginação, qual uma bomba, explode ligada ao estopim de um ruído estranho, de uma ideia maligna, de uma sensação incerta. Acelerada, estilhaça-se em mil reflexos [...] e engendra o medo, a ansiedade e a insegurança, a ponto de materializar-se em objetiva ameaça [...] Povoada pela imaginação compulsiva, a mente se transforma numa caldeira progressivamente aquecida [...] A cabeça não desliga, não adormece, não se desacelera, nem se pode espatifá-la a um canto da parede [...] (BETTO, 1987 , p. 53).

O controle das necessidades fisiológicas é outro problema enfrentado pela personagem-título no encarceramento. Não havia penico nem banheiro na solitária. Só lhe era permitida uma ida ao banheiro ao dia. Sendo assim, o narrador retrata a dificuldade do prisioneiro ao ter de conter suas excrecências: 
Sentiu a bexiga formigar. Até que viessem buscá-lo para ir ao banheiro, era preciso controlar-se, segurar o mais possível, em meio ao absurdo esforço de fazer a cabeça pensar em outra coisa enquanto as entranhas se liquefazem, como alguém que insiste em continuar lendo, sentado no sofá da sala, com as águas de uma inundação a subir-lhe pelas pernas (BETTO, 1987, p. 35-36).

O episódio referente ao corredor polonês, quando Ângelo recebeu socos, chutes, joelhadas, cotoveladas e cuspidas de quarenta soldados, é outro momento de tensão. Aliás, uma vez que a narrativa retrata o último dia de vida de um prisioneiro político, praticamente todas as páginas do romance são ambientadas em um clima extremamente tenso. Com exceção, obviamente, do segundo movimento, que apresenta uma ambientação mais luxuosa e sofisticada. Ao término do horripilante episódio de espancamento, o narrador nos diz:

do outro lado, estendido no chão, escutou risadas e vozes que o chamavam de doido e de bicha e, entre dores por todo o corpo, tentou segurar com a mão a rosa de sangue que aflorou em sua boca. Ergueu a cabeça, pediu água. Atiraramlhe um imundo pano de chão, nas costas uma vassoura e o obrigaram a limpar a cela (BETTO, 1987, p. 59).

O momento fatídico é relatado pelo próprio assassino confesso de Ângelo. Um ex-pugilista que prestava serviços escusos para os militares. Os requintes de crueldade são pontuados em riqueza de detalhes:

afundei a cabeça dele no vaso da privada, dei-lhe uma afogada a fim de soltar a língua e ele estrebuchou, engoliu água com mijo, fez aquela cara de pavor [...] até que o exército ficou de saco cheio e ordenou que eu pusesse "ponto final" e eu meti a mãozão na goela dele e apertei a sua cara na água da privada, apertei, apertei até que ele parasse de estrebuchar, a vida foi saindo do corpo que arriou ali no banheiro (BETTO, 1987, p. 133).

Em todos esses momentos, o leitor sofrerá com Ângelo. Sentirá a sua angústia e a sua dor. Solidarizar-se-á com o horror por ele vivido. Segundo Rorty (2007, p.293), “a única coisa que compartilhamos com todos os outros seres humanos é o mesmo que compartilhamos com todos os outros animais - a capacidade de sentir dor". A representação da dor alheia faz com que ela seja partilhada pelos leitores, que, se não sentem uma dor física no ato da leitura, ao menos a sentem no plano das emoções. Desse modo, os leitores se solidarizam com a dor sentida pela personagem-título, porque eles 
mesmos, os leitores, também sabem o que é sentir dor. Cria-se, assim, um sentimento de empatia entre o leitor e a personagem enviesada pela dor. De modo que a dor sentida por Ângelo, se torna a dor dos leitores.

Destarte, o que se vê é a representação dramática dos últimos momentos de um prisioneiro político, a quem foram impingidos tanto sofrimentos físicos quanto psicológicos. Há, portanto, uma carga emocional envolvida na construção da narrativa. O romance, diferentemente de textos historiográficos, apresenta a percepção das reações humanas às mais diversas situações, entre elas, a dor e a tortura. Os textos historiográficos e memorialísticos sobre o período em questão podem até expor os sentimentos vividos pelas personagens históricas, todavia não o farão nas mesmas proporções de um romance. Isso porque a narrativa potencializa os sentimentos de suas personagens e intensifica a percepção de vida delas. A literatura, desse modo, tem o poder de fornecer uma percepção mais intensa dos acontecimentos.

Em O dia de Ângelo, Frei Betto traz à baila a representação da crueldade humana imposta por uma coletividade (um regime totalitário) a um indivíduo em particular (um prisioneiro político). Destarte, ao escrever um romance sobre a tortura e o assassinato desumano de um preso político, Frei Betto, de certa forma, apresenta a crueldade como temática central da obra, que, embora escrita no período da Constituinte, enfoca as barbáries do governo militar (1964-1985). Ao se referir à crueldade, Rorty (2007, p. 243) dirá: "Mais importante, porém, é que ambos [isto é, os romances de Nabokov e de Orwell] satisfizeram o critério do liberal proposto por Judith Shklar: alguém que acredita que a crueldade é a pior coisa que fazemos". Se a crueldade é, de fato, a pior coisa que um ser humano pode cometer, ao enfatizar a prática da crueldade, o romance de Betto realça aquilo que há de pior na espécie humana, denunciando, desse modo, o lado sombrio da humanidade.

\section{A representação em Hotel Brasil}


Entre os grupos sociais que se destacam em Hotel Brasil (2010), o das crianças de rua ou menores infratores é um dos mais significativos para a análise da representação. Anderson Mata, ao falar sobre o lugar da infância na narrativa brasileira contemporânea, diz:

estudos apontam que apenas $7,9 \%$ das personagens masculinas e $6,4 \%$ das femininas têm suas infâncias representadas nos textos. Esses dados levam em consideração os textos em que as personagens são crianças em qualquer ponto da narrativa, o que nos leva a supor que o número de personagens que permanecem crianças ao longo de todo um romance seja ainda menor (MATA, 2015, p. 13).

Se as crianças, na narrativa brasileira contemporânea, têm sido relegadas ao olvido, isso não ocorre em Hotel Brasil, ainda que as crianças representadas nesse romance se encontrem destituídas de uma infância tradicional e pueril, assemelhandose mais a adultos em miniatura. É necessário frisar, no entanto, que Betto privilegia a narração da infância no tempo presente, diferentemente de autores que a retratam a partir das memórias de um personagem adulto. As personagens são, portanto, crianças e se mantêm crianças ao longo de todo o romance, não havendo espaço de tempo suficiente na narrativa para que elas se tornem adultas.

Bia, Soslaio, Bola e Taco adentram na história lá pela metade do enredo. Os quatro são introduzidos na narrativa no episódio em que "cerca de uma centena de meninos e meninas tinham escapado das unidades correcionais" (BETTO, 2010, p. 147). Os policiais, com cassetete à mão, espancavam os garotos e as garotas que se encontravam em meio à rebelião. Nesse instante, tanto Cândido quanto os vizinhos do reformatório solicitam aos policiais que parem de surrar os menores, mas não são atendidos.

As quatro crianças do romance tiveram sua infância ceifada tanto pela desigualdade social quanto pela desestruturação familiar. A representação proposta por Betto é, na verdade, a de uma não infância ou a da negação da infância. A infância tradicional inexiste em Hotel Brasil. Aliás, na narrativa de Betto, as crianças nunca aparecem brincando. Elas estão ou roubando, ou matando, ou se drogando ou fazendo 
sexo. $\mathrm{O}$ que se percebe, portanto, é que o romance narra o sequestro da infância pela pobreza, pelo crime, pelo trabalho, pelas drogas e pela sexualidade.

No único momento da narrativa em que aparece um brinquedo, o intuito não é a diversão nem a brincadeira. Bia retorna do Paraguai, disfarçada de filha do motorista de um caminhão. No colo, a menina carrega um urso de pelúcia praticamente do seu tamanho. Na alfândega, "os fiscais liberaram o caminhão, indiferentes à menina abraçada ao urso que trazia no ventre, cocaína suficiente para abastecer, por um mês, o tráfico na favela do Pavão-Pavãozinho" (BETTO, 2010, p. 240). Segundo Dalcastagnè (2018), algo muito parecido acontece no romance Cidade de Deus, de Paulo Lins. Para ela, "como lembra Anderson Luís Nunes da Mata, empinar pipa em Cidade de Deus, por exemplo, é muito mais uma estratégia de segurança do tráfico (o sistema de alerta para a chegada da polícia) do que uma brincadeira para crianças" (DALCASTAGNÈ, 2018, p. 182). De igual modo, o urso no colo de Bia serve ao tráfico e não à brincadeira, demonstrando assim a infância negada àquela menina.

O sequestro da infância em Hotel Brasil é revelado também pela trajetória de vida das próprias crianças. Bia, por exemplo, não sabia quem eram seus pais, fora criada em um orfanato dirigido por freiras. Quando a direção da casa passou ao poder público, as crianças sofreram maus-tratos pelos novos funcionários. A partir de então, Bia preferiu morar na rua. Se viver nas ruas não é fácil nem digno sequer para um adulto, imaginese, então, para uma menina com menos de doze anos. Onde moraria? O que comeria? Como sobreviveria, afinal? Bola, por sua vez, trabalhava como engraxate para sustentar o vício da mãe. Além disso, ele sempre presenciara o espancamento da mãe pelo pai. Seu irmão mais velho, por não ter tomado a vacina da poliomielite, ficou paralítico. A culpa foi do pai. Segundo o narrador, "no dia da vacina, pouco depois do sexto aniversário de Chico, o pai espancou a mulher porque, cedo, ela ligara o rádio [...] O pai perdeu a calma, Chico, a vacina. Depois, a doença atrofiou as pernas do menino" (BETTO, 2010, p. 148). Uma mãe alcoólatra e um pai espancador, o que esperar desse menino? Sobre Taco, o narrador apresenta o estado deplorável em que ele e a avó viviam na favela: "Deram uma espiada no barraco, um único cômodo feito de ripas, papelão e latas, obliquamente equilibrado sobre uma poça de lama. Ali, Taco e a avó dividiram o exíguo espaço com ratazanas e baratas vomitadas pelo esgoto aberto ao lado" (BETTO, 2010, p. 233). Além 
disso, ficamos sabendo que ele era um garoto negro (BETTO, 2010, p. 233). Desse modo, temos a descrição precisa do menino Taco: pobre, negro e favelado.

Os quatro infantes da narrativa acabam enveredando pelo submundo das drogas e da criminalidade. As crianças chegam a cometer assassinatos. Certo dia, pela manhã, Taco chegou ao barraco onde morava com a avó excitado pelo uso de cocaína. Totalmente perturbado, não se conteve diante da insistência da avó para que buscasse pão. Pegou a panela de ferro com resto de feijão e acertou a cabeça da velha. Depois disso, “dormiu horas ao lado da avó desacordada para sempre” (BETTO, 2010, p. 155). No dia da reconstituição do crime, Taco acabou sendo linchado pela multidão ensandecida. Ao fim da descrição da cena de linchamento, o narrador observa: "No chão, o que restou de Taco formava uma pasta misturada com lama. Destacavam-se apenas as cores verde e amarela da corda usada para estrangulá-lo” (BETTO, 2010, p. 235). As cores da corda com a qual Taco foi morto são as mesmas cores que estampam a bandeira brasileira. Ao que parece, o narrador culpabiliza o Estado pela morte do menino. Ao não garantir políticas públicas que viabilizem retirar os menores de condições absolutamente desfavoráveis e indignas, o Estado brasileiro estaria condenando suas crianças à morte. O outro assassinato é cometido por Bia. Ela mata Soslaio pelo fato de ele ter entregado o paradeiro dela à polícia. A fim de criar coragem para cometer o crime, Bia cheira cola e esmalte. Chapada, a menina segue Soslaio até um cinema. O narrador nos conta que, "na tela, tiros de rifles e o tropel de búfalos e cavalos abafaram o grito que o menino escutou, virando-se. Ela deu o primeiro tiro. Ele se jogou no vão entre a mureta do corredor de entrada e a última fila de cadeiras. Ela disparou de novo e acertou-o na cabeça" (BETTO, 2010, p. 202-203).

Pois bem, as quatro personagens, até então retratadas, são crianças ou bandidos? Vítimas ou delinquentes? Culpados ou inocentes? Em Literatura e Diretos Humanos, os organizadores escrevem o seguinte, na apresentação dos capítulos do livro:

Enquanto se ouvem os brados lá fora, nas ruas, nas redes sociais e nos palanques, de que "bandido bom é bandido morto" e de que defensores de direitos humanos devem ser eliminados (como de fato são, em todos os cantos deste país), tentamos buscar outras narrativas, que nos permitam acreditar que a barbárie não é o nosso único futuro possível. A literatura se torna, assim, espaço de interlocução e abrigo. Não toda ela, porque a arte também pode servir 
aos poderosos, domesticada e conivente. Interessa, aqui, a literatura que nos ajuda a refletir sobre nosso lugar no mundo e sobre o lugar do outro, sobre como nosso conforto pode estar atrelado à situação desesperadora de tantas pessoas. Interessa a literatura que nos permite pensar juntos sobre como pudemos chegar neste ponto, que nos indague sobre a nossa participação, ou a nossa omissão, diante de perseguições, ameaças, golpes, tiros e chutes (DALCASTAGNÈ; DUTRA; FREDERICO, 2018, p. 9).

O romance Hotel Brasil convida os leitores a refletir tanto sobre o seu lugar no mundo quanto sobre o lugar do outro. Aqui, não se pensa especificamente em Direitos Humanos, mas, sim, no direito à infância, tal qual preconizado pela ONU, na Declaração Universal Dos Direitos das Crianças. Mata (2006), ao analisar a infância no romance Cidade de Deus, observa:

Às crianças de Cidade de Deus foram subtraídos grande parte dos direitos universais à criança, declarados em documento da Organização das Nações Unidas em 1959. Da lista da ONU constam educação, recreação, amor, compreensão, habitação, alimentação, assistência médica, proteção contra a negligência, a crueldade, a exploração, e a discriminação racial ou religiosa, e, principalmente, condições dignas e livres de desenvolvimento, estendidos, sem exceção alguma, a todas as crianças (MATA, 2006, p. 51).

As crianças de Hotel Brasil, de modo semelhante, foram ceifadas de praticamente todos os direitos declarados pela ONU. Não se encontravam matriculadas em escola alguma, de modo que não lhes era facultado o direito à educação. Nunca aparecem brincando, sendo, portanto, privadas do direito à recreação. Moram nas ruas ou em moradias indignas, como aquela em que moravam Taco e sua avó, edificada com ripas, papelão e latas. Além disso, eram também carentes de afeto, uma vez que não lhes era dispensado nenhum tipo de amor e carinho. Ao contrário, sofriam maus-tratos em casa, no orfanato, no reformatório, nas ruas, etc. Tal carência se evidencia, por exemplo, quando Bia pergunta a Cândido e à Mônica se eles não gostariam de ser seus pais. As crianças ainda eram exploradas, como é o caso de Bola, que trabalha para manter o vício da mãe. Além do que, pode-se dizer que os quatro não dispõem de nenhum tipo de proteção: nem contra a crueldade nem contra a exploração, muito menos contra a discriminação. Aliás, eles são discriminados pelo simples fato de serem crianças de rua e, por esse mesmo motivo, são tidos como trombadinhas em potencial. 
Outro aspecto do romance Hotel Brasil concerne à representação da crueldade. Os mais "fracos" sofrem em demasia nas mãos dos mais "fortes". Isso nos faz refletir acerca da assimetria do poder. Para Foucault (1990, p. 250) "na medida em que as relações de poder são uma relação desigual e relativamente estabilizada de forças, é evidente que isto implica um em cima e (um embaixo, uma diferença de potencial”. No caso de Hotel Brasil, a força relativamente estabilizada dos mais "fortes" sobre os mais "fracos" se evidencia, principalmente, por meio da violência física. O pai de Bola, por exemplo, agride fisicamente a mãe do menino. Os menores infratores, durante a fuga da unidade penal, são espancados pelos policiais. Bola é surrado pelos seguranças de uma confeitaria por flertar com um doce exposto na vitrine. O faxineiro do hotel, Jorge Maldonado, um sujeito sem eira nem beira, é torturado pela polícia a fim de confessar um crime que não cometeu. A menina Bia é pega por um grupo de extermínio, composto por policiais, a mando de comerciantes locais; contudo, devido a um acidente de trânsito envolvendo o veículo no qual a menina seguia sequestrada, ela conseguiu fugir.

Além disso, Betto retoma a temática de O dia de Ângelo retratando, novamente, a crueldade empregada pelo regime militar àqueles que lhe faziam resistência. Mônica conta a Cândido, em detalhes, o dia em que foi violentada por engano pelos militares. Quando estudante, ela participou de uma passeata contra a intervenção dos generais nas escolas. Foi presa, vendada e posta em um carro. Ao chegarem a determinado lugar, foi conduzida a uma sala onde uma senhora a aguardava. Mônica relata o que ocorreu na sequência:

\footnotetext{
"A mulher estendeu a mão. Senti um beliscão no braço e gritei de dor. "Isso é só o aperitivo", alertou a mulher [...] "A senhora se enganou de Mônica", ponderei, mas a mulher gritou, xingou, disse que iria refrescar a minha memória. “Tire a roupa!", ordenou. Comecei a tremer, a sentir meu corpo gelar, e tirei a camiseta e a calça comprida. A mulher aproximou-se e arrancou o meu sutiã. “Tire a calcinha!", berrou. Fiquei nua, tomada pelo pânico [...] A mulher colou-se em mim, apertou-me o bico do seio e indagou: "Pela última vez, onde está o Alexandre?" Empurrou-me para trás antes de escutar a resposta e me deu um chute na altura dos rins. Encolhi-me no chão, rogando a Deus que me permitisse antes morrer do que sofrer [...] Logo que saiu, entrou um homem atarracado, imenso de gordo. Vestia apenas uma sunga. Caminhou qual um urso em direção a mim e, com um sorriso sarcástico, agarrou-me pelo braço e arrastou-me ao colchonete: "Vem, beleza, vou fazê-la gozar até decidir contar onde está o Alexandre." [...] Horrorizada, continuei reagindo, dando pontapés, mas em seguida o homem tirou a sunga e me deu um safanão que me fez perder
} 
os sentidos. Ao acordar, vi que estava só na sala. Sentia frio, minha vagina ardia e sangrava, meu corpo estava coberto de hematomas e arranhões." (BETTO, 2010, p. 245-247).

Segundo Soares (2016, p. 72), "os torturadores (devidamente treinados) conheciam os limites dos torturados, sabiam como fragilizar e atacar os corpos para obter informações. Existiam meios de tortura psicológica para desmoralizar o preso político, como a técnica de logo retirar a roupa do mesmo". A nudez é uma forma de desestabilizar o indivíduo, tornando-o vulnerável. A roupa nos serve como uma forma de proteção. Ao sermos despidos, contra nossa vontade, nos sentimos envergonhados, desonrados e fragilizados. Não obstante, os torturadores de Mônica não se dão por satisfeitos simplesmente com sua nudez. Vão além, estuprando-a, transgredindo, desse modo, o direito mais básico do ser humano, que diz respeito à sua integridade física e mental. O estupro, antes de ter relação com a sexualidade, é uma questão de poder. Um poder exercido à força, sem o consentimento de uma das partes envolvidas no ato.

\section{A representação em Aldeia do Silêncio}

Em Aldeia do silêncio (2013), Frei Betto aborda a representação do campo e da cidade. Raymond Williams principia seu livro $O$ campo e a cidade na história e na literatura dizendo:

\footnotetext{
"Campo" e "cidade" são palavras muito poderosas, e isso não é de estranhar, se aquilatarmos o quanto elas representam na vivência das comunidades humanas [...] Na longa história das comunidades humanas, sempre esteve bem evidente essa ligação entre a terra da qual todos nós, direta ou indiretamente, extraímos nossa subsistência, e as realizações da sociedade humana. E uma dessas realizações é a cidade: a capital, a cidade grande, uma forma distinta de civilização (WILLIAMS, 2011, p. 11).
}

Contudo, segundo Williams (2011), campo e cidade são vistos de modos diversos ao longo da história. Se existem aqueles que enaltecem o campo, também existem aqueles que o depreciam. $\mathrm{O}$ mesmo acontece com a cidade, que ora é vista com bons 
olhos, ora é representada em um tom um tanto ou quanto sombrio. Nas palavras de Williams:

O campo passou a ser associado a uma forma natural de vida - de paz, inocência e virtudes simples. À cidade associou-se à ideia de centro de realizações - de saber, comunicações, luz. Também constelaram-se poderosas associações negativas: a cidade como lugar do barulho, mundanidade e ambição; o campo como lugar de atraso, ignorância e limitação (WILLIAMS, 2011, p. 11).

O que Williams fará, em boa parte de sua obra, é observar como o campo e a cidade são representados pelos escritores ingleses ao longo dos séculos. Aldeia do silêncio, por sua vez, apontará o contraste entre esses dois tipos de comunidade humana, o campesino e o urbano, no contexto brasileiro. Na narrativa bettiana, o local sempre almejado é o campo em detrimento da cidade. Há uma oposição, a nosso ver irreconciliável, entre campo e cidade em Aldeia do silêncio. O campo é, portanto, representado sempre de maneira positiva, enquanto a cidade é representada sempre de forma negativa.

A aldeia é para Nemo o local onde reina a felicidade: "Por laços de afinidade, encerrados naqueles confins, estávamos condenados à felicidade, malgrado a desolação circundante" (BETTO, 2013, p. 32). Contudo, essa felicidade é desfeita pelo progresso, bem como pela violência por meio da qual Nemo e sua mãe são enxotados da aldeia. Quando o pai de Nemo vem avisá-los que vendeu a aldeia e que ali seria construído um clube de golfe, ele diz o que segue: "Já que não querem ir ao progresso”, ironizou, “o progresso virá a vocês" (BETTO, 2013, p. 174). Como resposta, o narrador em primeira pessoa faz a seguinte observação: "Foi então que teve início a nossa infelicidade" (BETTO, 2013, p. 175). Em Aldeia do silêncio, cidade e progresso são termos sinonímicos que apontam um tipo de sociedade humana desafortunada. Em relação ao progresso, vale ressaltar o episódio no qual a aldeia foi invadida por um tufão, trazendo uma fuligem que enegreceu o rosto de seus três moradores, ocasionando até falta de ar. $\mathrm{O}$ avô, então, resmungou: "Isso é lixo do progresso" (BETTO, 2013, p. 77). Por não saber o que era o tal progresso, o personagem-narrador pontua: "Fiquei matutando: o progresso..." (BETTO, 2013, p. 77). Por causa da forma como o progresso é representado, 
ao longo da narrativa, não é difícil imaginar o que se passa na cabeça de Nemo ao "matutar" sobre o progresso.

O que torna a aldeia um local tão desejado é o silêncio. Nela, o silêncio se encontra envolto em certo misticismo. O personagem-narrador nos diz que "na aldeia, nossa entrega ao silêncio obedecia a uma metafísica inconceituada, uma vez que o encontro com o outro era o encontro consigo, como se a voz silenciosa do Mistério fizesse ressoar, no íntimo, um convite à comunhão" (BETTO, 2013, p. 61). Perante a policromia de um crepúsculo, por exemplo, o avô, a mãe e Nemo contemplavam o entardecer sem nada dizer um ao outro. O narrador quebra o silêncio dizendo que "há momentos tão sublimes que pronunciar qualquer palavra é profanação” (BETTO, 2013, p. 45).

A cidade, por sua vez, é representada como um lugar barulhento, cheio de ruídos e com um ritmo alucinado. Para o personagem-narrador, "há demasiadas palavras na cidade. Muitos se expressam por outros dizeres: ruídos, agitação, poluição... A cidade é tagarela e, nessa verborragia, se perde como lugar acolhedor" (BETTO, 2013, p. 183). Se a tônica do romance gira em torno do silêncio, a cidade pode ser entendida como a grande vilã da história. Nela não há silêncio.

É possível, no entanto, compreender a aversão de Nemo pela cidade. De certa forma, ele representa aqueles que foram tragados pelos grandes centros urbanos. Ao ser praticamente cuspido na cidade, sem dinheiro, sem conhecidos e sem ter como ganhar a vida, ele se torna mendigo. Revira latas de lixo em busca de alimento. Dorme nas praças e nas calçadas. É maltratado por outros mendigos. Enfim, Nemo se torna "apenas um lixo ambulante travestido do que outrora fora um ser humano" (BETTO, 2013, p. 181). Em certo momento da narrativa, ele desabafa:

Tenho medo da cidade. Voraz, ela nada tem de veraz [...] Nem cheguei a me sentir como Jonas no ventre do peixe. Jonas sobreviveu, não foi deglutido pelo animal que o devorou. Não tive a mesma sorte. A cidade, com sua voracidade consumista, triturou-me [...] Tudo tem importância, menos eu (BETTO, 2013, p. 186).

Há, portanto, uma relação entre exclusão social e cidade. Segundo consta, as cidades possuem várias faces, e uma única cidade é capaz de abrigar, ao menos, duas 
cidades: "a oficial, na qual circulam os cidadãos, e a não oficial, restrita a grupos e/ou segmentos sociais dela e por ela excluídos" (LIBERATO, 2007, p. 15). Ao vir do campo para a cidade, Nemo se vê obrigado, após deixar a delegacia, a viver nas ruas. O drama de Nemo é o drama daqueles que enfrentam o êxodo rural, sendo enxotados do campo para a cidade. Ao aportarem nos grandes centros urbanos, essas pessoas passam a viver à margem tanto geograficamente quanto socialmente. Isso ocorre, principalmente, em consequência de sua condição socioeconômica, bem como da falta de qualificação profissional que os leva a ocuparem atividades de baixo status e com baixa remuneração.

Além da relação contrastante entre campo e cidade, o romance de Betto traz à tona a questão fundiária. Os fazendeiros ou latifundiários expulsam cruelmente os campesinos de suas terras. Há uma reforma agrária às avessas. O que se vê no romance é a ampliação das terras dos grandes proprietários, enquanto os pequenos são obrigados a migrar para as cidades. Segundo o narrador,

veio a ganância, fincou estacas entremeadas de arame farpado, e delimitou espaços. Na fazenda despontou, imponente, a casa-grande; o proprietário, enfiado em botas de canos altos, exibiu papéis; a Justiça exigiu recibo das famílias. Não foi aceito o apalavrado, o fio do bigode, e a traição anulou a tradição. O que era perdeu valia (BETTO, 2013, p. 7o).

Williams (2011), falando sobre a posse da terra, diz o seguinte: "pouquíssimos títulos de propriedade, se investigados, se revelariam livres de mácula, no longo processo de conquista, roubo, intriga, política, favoritismo palaciano, extorsão e poder do dinheiro" (p. 87). Embora Williams fale a partir da realidade inglesa, seria a questão da propriedade rural diferente em terras tupiniquins? Ao que parece, no excerto acima, Betto relata a questão da grilagem de terras. Isso porque, na continuidade da narrativa, jagunços são acionados a fim de expulsarem aqueles que habitavam as terras do povoado. A crueldade utilizada pelos grileiros contra os camponeses é registrada pelo narrador:

Envenenaram o curso d'água, velhos murcharam afogados em tosses, crianças amarelecidas naufragaram em vômitos, homens e mulheres definharam. Cortaram cercas, descarnaram o gado, roubaram porcos e galinhas. Fizeram arder em fogo a plantação e destruíram as casas, mordidas pelos dentes gigantes de escavadeira. Restou a capela. Um ou outro tentou resistir, mas as armas da 
jagunçada calaram os clamores. Aquela terra adubou-se de sangue (BETTO, 2013, p. 70).

A grilagem no Brasil iniciou quando os portugueses aqui desembarcaram, apossando-se das terras indígenas. A partir daí, houve uma distribuição absolutamente desigual das terras em solo brasileiro - em decorrência de diversos fatores, entre eles a grilagem - formando-se, assim, os grandes latifúndios. Márcia Motta ${ }^{3}$ (2001) nos diz o seguinte sobre a grilagem no contexto brasileiro:

Nunca é demais refletir sobre o que herdamos no século XXI. Sobre o universo rural, não há dúvidas: nossa herança é o espólio não partilhado, fruto de uma história mais do que secular de um poder (às vezes sem limites) dos senhores $e$ proprietários de terra e de grilagens realizadas diante dos olhares cúmplices dos representantes da justiça (MOTTA, 2001, p. 1).

No romance, a grilagem aparece associada à violência. Além do trecho há pouco elencado, que revela a crueldade contra os ocupantes do povoado, há outro fragmento que merece ser destacado. Nemo narra aquilo que lhe fora contado pelo avô a respeito da brutalidade utilizada pelos fazendeiros e latifundiários contra os pequenos agricultores:

Não consideram suficiente dar um tiro na cara do lavrador que resiste à proposta de vender sua terra por uma ninharia. Preferem emboscá-lo na estrada, arrancar-lhe as unhas, espremer-lhe os bagos, queimar-lhe a pele com pontas de cigarro e, por fim, cravar-lhe uma bala na nuca para que gente como ele aprenda, de vez por todas, que não se ousa deter a gula quando se trata de devorar mais e mais terras (BETTO, 2013, p. 72).

A prática da tortura nos romances de Frei Betto não está associada apenas à polícia e aos militares. Quem pratica a tortura em Aldeia do silêncio, ao menos nesse episódio, são os jagunços contratados pelos fazendeiros e latifundiários. Na verdade, os fazendeiros não agem com desumanidade apenas contra os pequenos proprietários de terras, como também o fazem contra seus próprios empregados. Novamente, Nemo apresenta as reminiscências do avô:

\footnotetext{
${ }^{3} \mathrm{O}$ artigo de Márcia Maria Menendes Motta, "A grilagem como legado", foi originalmente publicado no livro Voluntariado e Universo Rural (2001). Contudo, a versão utilizada neste artigo se encontra disponível em: http://www.direito.mppr.mp.br/arquivos/File/Politica_Agraria/7MottaAGrilagemcomoLegado.pdf.
} 
E acrescentou que, da época do povoado, ele ainda sentia pontadas de muitas feridas, pois se alembrava de coisas ruins, como maus-tratos do dono da fazenda, maus-tratos aplicados não pelo próprio dono, mas por seus capatazes, como sempre acontece quando uma pessoa poderosa faz mal aos outros: ela nunca põe as mãos na massa, jamais as suja de sangue, dá um jeito para que outros façam isso por ela [...] (BETTO, 2013, p. 72).

No povoado, que antecedeu a aldeia, “cada família cultivava o próprio roçado. Ninguém padecia desventuras; frutos de um, desfruto de todos" (BETTO, 2013, p. 69). Contudo, nas palavras da mãe de Nemo, o povoado "adoeceu de opressão". O romance nos conta que:

[...] a fazenda se expandiu no rumo do povoado e o burro sumiu nos matos. Certa manhã, o encontraram morto na beira do córrego. Derramava sangue pelo buraco do tiro que lhe abrira a cabeça. Os moradores não tinham mais como carregar lenha, pedras ou água. Acuados pelo latifúndio, arrastaram suas vidas até que a dama da foice viesse buscá-los. Houve o envenenamento da água e o incêndio da casa-grande. Sobraram o avô, a mãe e o pai com o irmão que já havia nascido" (BETTO, 2013, p. 73).

A tortura sofrida pelo personagem-narrador, preso por se recusar a abandonar a aldeia, traz novamente à tona a barbárie cometida contra a camada mais fragilizada da sociedade. A narrativa nos diz que, após expulsarem Nemo da aldeia, ele foi conduzido a uma delegacia. Na sequência, lemos as palavras do narrador-personagem:

Fui recebido aos gritos por policiais enfurecidos [...]. Pediram-me documentos. Nunca os tive. Perguntaram meu nome. Não tenho. Indagaram se eu tinha dinheiro. Eu não sabia o que é [...] Então me golpearam para me obrigar a falar. Quebraram-me os dentes, perfuraram-me o pulmão, atingiram meu rim (BETTO, 2013, p. 177).

Se na época da ditadura a tortura foi utilizada prioritariamente contra acadêmicos, intelectuais, jornalistas e políticos, pessoas com certa expressividade social, “a tortura de 'sempre' atinge os 'invisíveis' de sempre” (BARROS, 2015, p. 49). Historicamente, a tortura sempre foi destinada às classes menos favorecidas da sociedade. Ao tratar sobre a tortura no Brasil colônia, Barros (2015, p. 32) afirma que a grande maioria dos torturados naquele período eram os negros e os indígenas, ou seja, pessoas socialmente invisíveis e desfavorecidas. Em Aldeia do silêncio, Betto adverte seus 
leitores de que, em pleno século XXI, a tortura continua sendo praticada majoritariamente contra pessoas sem nenhuma expressão social. Mais um excerto de Barros (2015) nos ajuda a ratificar essa questão:

No Brasil, só há intolerância contra a tortura quando praticada contra membros das classes média e alta. A tortura dos pobres só é intolerável quando se difunde nos jornais e televisões, e aí a sociedade e as autoridades públicas se sentem obrigadas a se indignarem. (BARROS, 2015, p. 168-169)

Embora não haja no romance elementos concretos que nos permitam datar com precisão o ano em que o mesmo se passa, ainda assim existem indícios suficientes no texto para dizermos que o enredo, Aldeia do silêncio, se passa na contemporaneidade ${ }^{4}$. Destarte, se em um passado remoto a tortura era uma prática comum e sem maiores questionamentos, nos dias atuais ela se encontra em observação, embora ainda seja praticada em larga escala. Desse modo, uma das razões, entre as sete, oferecidas por Barros (2015, p.57) para a extinção da tortura, é a seguinte: “A terceira razão é porque há dois séculos se aboliu a tortura. Isso é um reflexo dos avanços históricos e culturais alcançados durante séculos, ou do que poderíamos denominar 'processo civilizador"'. Os romances de Betto, portanto, nos levam a refletir sobre os efeitos legais e morais da tortura, bem como a respeito da crueldade por ela exercida, que desumaniza os potenciais suspeitos de um crime tornando-os nada mais do que "animais", "vermes", “insetos” ou “coisas” (BARROS, 2015, p. 205).

\section{Considerações finais}

Aos analisarmos a representação na obra literária de Betto, percebemos que em seus três romances, os grupos sociais postos em evidência são grupos marginalizados ou

\footnotetext{
${ }^{4}$ Creio que o maior indício de indicação cronológica no romance, embora, de qualquer forma, não exista precisão, é o fato de a alfabetizadora de Nemo ter sido aluna de Erich Auerbach (1892-1957). Segundo o narrador-personagem, "Madame A. estudara na Universidade de Yale, nos Estados Unidos. Tinha sido aluna de um professor cujo nome anotei - Erich Auerbach" (BETTO, 2013, p. 102). Esse incidente, bem como do fato de Madame A. ser viúva e ter falecido durante os anos de internamento de Nemo, nos leva a pensar que o romance se passa nas últimas décadas do século XX ou nos primeiros anos do século XXI.
} 
malquistos pela sociedade. Em $O$ dia de Ângelo, um comunista é representado de forma positiva, enquanto os militares são vistos como vilões. Em Hotel Brasil, as crianças de rua alcançam visibilidade e são representadas como vítimas de uma sociedade excludente. Em Aldeia do silêncio, os camponeses, ou pequenos agricultores, são retratados como vítimas dos latifundiários, que não poupam esforços para lhes tomarem as terras (a qualquer custo!).

Prendergast (2000), como salientado no início do artigo, propõe uma discussão sobre o valor da verdade na representação. Para ele, no século XIX, o termo representação, ao menos no que diz respeito aos estudos literários, estava ligado "à ideia de um reflexo fidedigno e preciso da realidade" (PRENDERGAST, 200o, p. 4, tradução nossa). Entretanto, as teorias modernas sugerem exatamente o contrário. A representação, nessa nova perspectiva, é vista como alienante ou construtiva. Quando o que a regula é o discurso dominante, a representação é alienante. Contudo, à medida que legitima o ponto de vista dos oprimidos e dos dominados, a representação se torna construtiva. Ao desconstruir o discurso dominante a respeito dos prisioneiros políticos, das crianças de rua, bem como da desapropriação indevida de pequenas propriedades rurais (por meio da grilagem), Betto propõe uma representação desalienante em sua obra literária.

Ao propor, nos três romances analisados, a representação da tortura, Betto parece querer nos dizer que essa prática absolutamente condenável na atualidade se encontra “eternizada” na cultura brasileira. Segundo Barros (2015, p.50), “quando Luciano Oliveira muito acertadamente corrigiu o usual discurso de 'tortura nunca mais' e, parafraseando Nietzsche, intitulou seu livro sobre tortura de Do nunca mais ao eterno retorno, ele já sublinhava a constância da eternização da tortura no Brasil”. Não obstante, quando se fala em tortura no contexto brasileiro logo se pensa no ocorrido no período da ditadura militar (1964-1985); mas a tortura continua presente no âmbito policial até a atualidade. A literatura de Betto apresenta essa questão, mostrando que, infelizmente, a tortura permanece mais viva do que nunca. Nas palavras de Barros:

Temos cinco séculos de tortura, e toda vez que o tema vem à tona, aparece alguém fazendo referência à ditadura. É legítimo e justo que algumas organizações dediquem-se aos seus objetivos, tais como punir torturadores do 
regime militar. O que é inadmissível é os poderes constituídos, a imprensa, as organizações sociais e a sociedade em geral agirem como se apenas houvesse tortura política. Esquecendo que a tortura ocorre de forma sistemática e que recai, desde sempre, sobre uma determinada classe subalternizada, sem que se faça algo contra isso (BARROS, 2015, p. 256).

Além do que, ao trazer a representação da tortura para dentro da literatura, Betto nos faz ponderar e refletir sobre a crueldade e a desumanidade dessa prática. Barros (2015) diz que um dos motivos da "eternização" da tortura no Brasil é, justamente, a falta de debate sobre o tema. Quanto a isso busca-se respaldo em suas palavras:

o problema é que, no Brasil, não há uma discussão sobre justificantes morais para eventual prática da tortura. Chega a ser bizarro que, mesmo com toda a nossa tortura cotidiana, é mais fácil encontrar publicações que tratam da tortura nos EUA do que no Brasil [...]. (BARROS, 2015, p. 67)

Frei Betto, portanto, ao fomentar a discussão a respeito da tortura no campo literário faz com que seus leitores ponderem sobre o tema em questão a partir da representação presente em seus romances. A literatura, dessa forma, fornece sua contribuição de intervenção no mundo e na sociedade ao promover a discussão sobre um tema pouco discorrido em terras tupiniquins, embora, como já foi dito anteriormente, continue a ser amplamente praticado em território nacional.

A questão da crueldade também fica evidente nos três romances em apreço. Em O dia de Ângelo, há a ação violenta dos militares contra a personagem-título. Em Hotel Brasil, a crueldade acomete as crianças abandonadas, o zelador do hotel, torturado pela polícia, e Mônica, estuprada durante o regime militar. Em Aldeia do silêncio, a barbárie acontece contra os pequenos proprietários rurais. A se pensar na questão concernente à crueldade e sua relação com a literatura, Rorty (2007, p.243) nos diz o seguinte: “A principal semelhança em que insistirei neste capítulo e no próximo é que os livros de Nabokov e Orwell diferem dos que foram escritos pelos autores que discuti na segunda parte - Proust, Nietzsche, Heidegger e Derrida - no sentido de que a crueldade, e não a criação de si mesmo, é seu tema central”. Podemos, em consonância com Rorty, dizer que a crueldade é o tema central nos romances de Frei Betto. Isso porque Betto nos 
"ajuda a penetrar na crueldade e, com isso, contribui para articular a ligação tenuemente sentida entre a arte e a tortura" (RORTY, 2007, p. 244).

Entretanto, se o tema central da narrativa bettiana é a crueldade, qual seria o intuito do autor ao trazer para a literatura a temática da tortura e da violência dos mais fortes contra os mais fracos? Para Rorty (2007, p.281),

Escritores diferentes querem fazer coisas diferentes. Proust queria a autonomia e a beleza; Nietzsche e Heidegger queriam a autonomia e a sublimidade; Nabokov queria a beleza e a autopreservação; Orwell queria ser útil às pessoas sofredoras. Todos lograram êxito. Cada um deles foi brilhantemente e igualmente bem-sucedido.

Destarte, em nossa compreensão, Frei Betto parece querer reivindicar os direitos daqueles que deles são privados. Se a tortura, que é um ato desumano, é tratada à exaustão nos romances bettianos, a violação dos direitos humanos, portanto, se apresenta como uma denúncia evidente em suas obras. Desse modo, se "Orwell queria ser útil às pessoas sofredoras”, Betto, por sua vez, quer ser útil às vítimas da violência e da tortura, evocando a violação dos direitos humanos não apenas pela polícia, representantes do Estado, mas também por particulares, como os latifundiários.

Como ficou perceptível, refletir sobre a representação literária na obra ficcional de Frei Betto nos levou a ponderar sobre a relação entre literatura e poder, literatura e direitos humanos, bem como literatura e política. A representação na obra ficcional bettiana convida os leitores a perceberem as agruras presentes em nossa sociedade e, desse modo, os sensibiliza a se solidarizarem com as personagens sofredoras e torturadas, tornando os leitores seres mais politizados e mais preocupados com a realidade a sua volta.

Por fim, tornemos ao pensamento de Rorty sobre os romances de Dickens. Para o filósofo norte-americano, os romances dickensianos são capazes de conduzir os leitores a inclusão e a generosidade: "Se nós fizermos de Dickens o paradigma do Ocidente, como eu acho que meus africanos e asiáticos fantasiosos o fariam, então nós veremos que o aspecto mais instrutivo na recente história do Ocidente é sua capacidade 
de tolerar a diversidade" (RORTY, 1999, p. 112)5 . De modo semelhante, os romances de Betto analisados neste artigo são um convite à tolerância (a fim de nos conduzir à reflexão sobre o assunto). A tortura e a violência fomentadas em seus textos ficcionais auxiliam, desse modo, nas discussões a respeito da intolerância à diversidade. $\mathrm{O}$ que se percebe, portanto, é que a narrativa bettiana se preocupa em apresentar a intolerância política, a intolerância contra os menores abandonados, a intolerância para com os pequenos proprietários rurais, além da intolerância para com aqueles que são vomitados nos grandes centros urbanos.

\section{Referências}

BARROS, Marcelo. Polícia e tortura no Brasil: conhecendo a caixa de maçãs podres. Curitiba: Editora Appris, 2015.

BETTO, Frei. O dia de Ângelo. 3. ed. São Paulo: Editora Brasiliense, 1987. Hotel Brasil, o mistério das cabeças degoladas. Rio de Janeiro: Rocco, 2010. Aldeia do silêncio. Rio de Janeiro: Rocco, 2013.

DALCASTAGNÈ, Regina. Sobre guerras, ruídos e esquecimento. In. Literatura e Direitos Humanos. DALCASTAGNÈ, Regina; DUTRA, Paula. Q.; FREDERICO, Graziele. (Orgs.). Porto Alegre: Editora Zouk, 2018, p. 181-188.

FOUCAULT, Michel. Microfísica do poder. $9^{\underline{a}}$ ed. Rio de Janeiro: Graal, 1990.

LIBERATO, Rita de Cássia. Cidade e exclusão: o lugar de moradia dos excluídos: o caso de Belo Horizonte. 2007. Tese (Doutorado em geografia: Tratamento de Informação Espacial) - Pontifícia Universidade Católica de Minas Gerais, Belo Horizonte, 2007.

\footnotetext{
${ }^{5}$ Alguém poderia questionar se existe tolerância à diversidade na sociedade ocidental. Quanto a isso, Rorty salientará, como desenvolvimento de seu raciocínio, algo importante a se registrar: "Pode parecer estranho atribuir esse tipo de boa vontade ao Ocidente recente - uma cultura frequentemente citada, com excelente razão, como sendo racista, sexista e imperialista. Mas ela também é claramente uma cultura que está muito preocupada quanto a ser racista, sexista e imperialista, tanto quanto a ser eurocêntrica, paroquial e intelectualmente intolerante. Ela é uma cultura que se tornou muito consciente de sua capacidade para a intolerância assassina; e, consequentemente, uma cultura que talvez tenha se tornado mais atenta frente à sua intolerância, mais sensível ao caráter desejável da diversidade, do que qualquer outra da qual nós tenhamos registro." (RORTY, 1999, p. 112).
} 
Disponível em: $\quad$ http://www.biblioteca.pucminas.br/teses/TratInfEspaci al LiberatoRC.pdf. Acesso em: 13 mai. 2019.

MATA, Anderson Luís Nunes da. O silêncio das crianças: representações da infância na narrativa brasileira contemporânea. 2006. Dissertação (Mestrado em Literatura) Universidade de Brasília, Brasília, 2006. Infância na literatura brasileira contemporânea: tema, conceito, poética. Estudos de literatura brasileira contemporânea, número 46, Brasília, jul/dez 2015. p. 13-20. ISSN 2316-4018. Disponível em: http://dx.doi.org/10.1590/2316-4018461. Acesso em: 25 jan. 2019 .

MOTTA, Márcia Maria Menendes. A grilagem como legado. Disponível em: http://www.direito.mppr.mp.br/arquivos/File/Politica Agraria/7MottaAGrilagemcomo Legado.pdf. Acesso em: 23 jan. 2019.

PRENDERGAST, Christopher. The Triangle of Representation. New York: Columbia University Press, 2000.

RORTY, Richard. Contingência, ironia e solidariedade. Martins Fontes: São Paulo, 2007. .Ensaios sobre Heidegger e outros Escritos filosóficos 2. Rio de Janeiro: RelumeDumará, 1999.

SOARES, Anderson da Silva. Discursos e representações do corpo durante a ditadura militar no Brasil (1968-1979). 2016. Dissertação (Mestrado em História e espaços). Universidade Federal do Rio Grande do Norte, Natal, 2016. Disponível em: https://repositorio.ufrn.br/jspui/handle/123456789/22118. Acesso em: 13 mai. 2019.

WILLIAMS, Raymond. O campo e a cidade na história e na literatura. São Paulo: Companhia das Letras, 2011.

Recebido em o7/o4/2020. Aprovado em 17/05/2020. 